\title{
UMA HISTORIA DE AMOR À ANTIGA ATRAVÉS DOS CARTÕES POSTAIS ${ }^{1}$
}

\author{
Ana Luiza Carvalho da Rocha
}

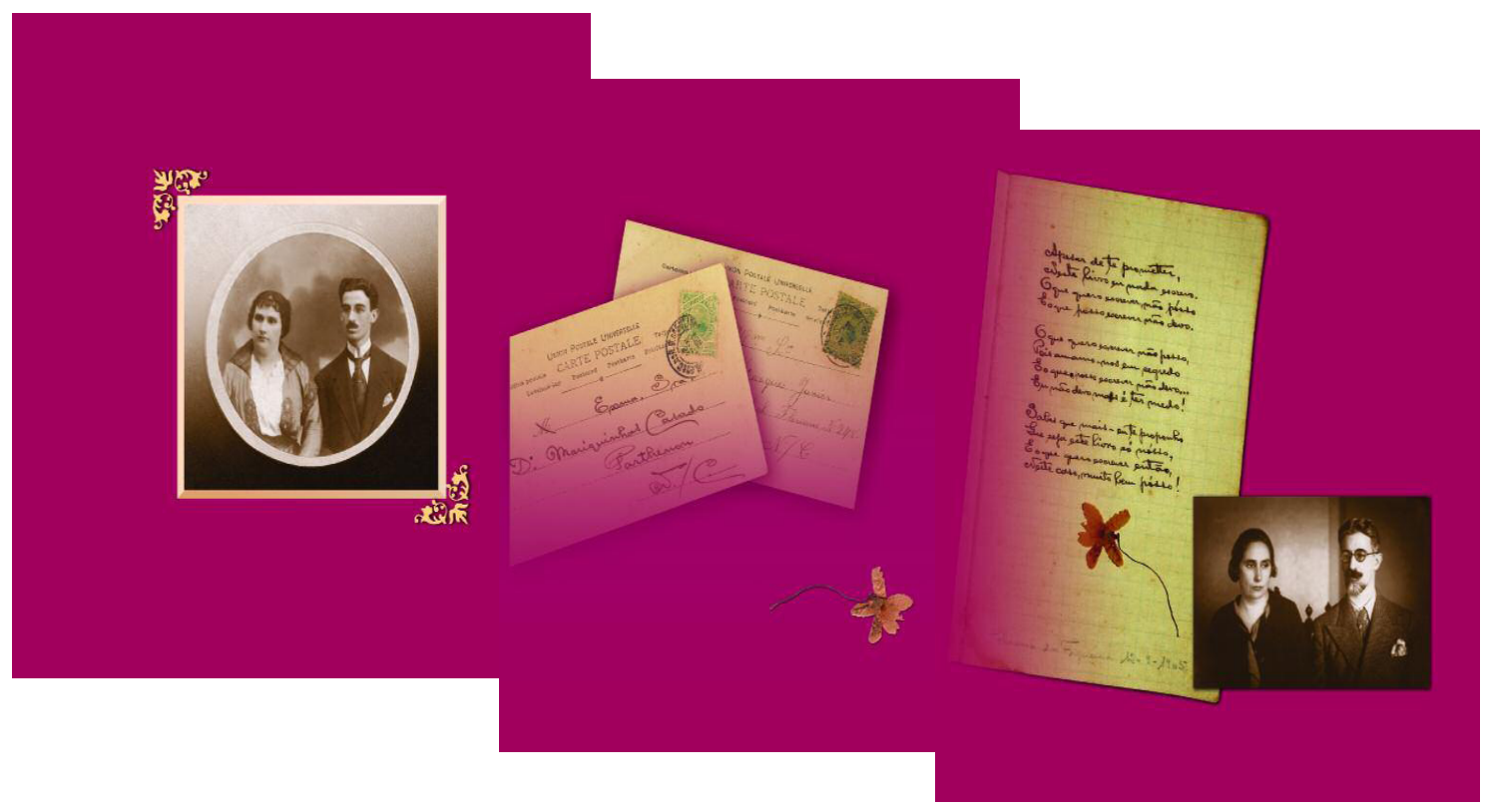

Olhar, hoje, para uma coleção de postais como esta que nós temos o prazer de trazer ao conhecimento do publico e que trata de um conjunto de belos e raros cartões trocados entre dois jovens e destes com sua rede de amigos, guardada há mais de 100 anos, numa pequena caixa de madeira por sua família, pode despertar uma simples curiosidade a respeito de fatos pitorescos ou esquisitos que marcaram as formas de sociabilidade entre rapazes e moças numa determinada época, na cidade de Porto Alegre.

Entretanto, acreditamos que entre muitas outras, há uma forma de olhar esta coleções de psotais, mais cuidadosa seria aquela que nos conduziria a compreender toda a complexidade das formas de sociabilidade que orientaram a vida destes dois jovens da amizade, ao namoro, ao noivado e, finalmente, ao casamento, pensando-se este ciclo no tempo e no espaço de duração de suas vidas.

Vamos convidar o leitor a apreciar os diferentes matizes que configuraram a troca de cartões postais no interior de uma rede social de jovens de camadas médias urbanas do qual resultou a historia de amor, entre Maria Angélica Casado (Mariquinhas) e Eduardo Marques Junior (Dudu), e que envolveu parentes e amigos do casal apaixonado. Uma historia de amor e de paixão entre dois jovens de Porto Alegre dos primórdios do século XIX que para ser compreendida na grandeza do gesto humano que ela representa nos convoca a pensá-la no interior de um espaço fantástico, o da memória coletiva das formas de expressão das relações de amizade e amorosas que herdamos de nossos antepassados.

1 Este texto deu origem a publicação e a exposição Cartophilia, uma história de amor, produzido por Maria Luiza Carvalho da Rocha e Vera Pellin, sob a curadoria de Alexandre Magalhães e Silva, com a subvenção da Caixa Cultural, em 2004. 
A singularidade da historia de amor entre Marquinhas e Dudu, neste ponto, nos lembra outras tantas historias anônimas de amor cujos traços não foram preservados e que foi objeto de estudos de toda uma literatura antropológica e histórica clássica versando sobre as transformações das regras de namoro, noivado e casamento nas sociedades ocidentais até nossos dias. A historia de amor que resultou deste costume de troca de postais nos lembra importantes estudos sobre a formação da família brasileira como os trabalhos de Gilberto Freire (1936, 1998), Thales de Azevedo (1981, 1986), Maria Isaura de Queiroz (1978), Thales de Azevedo e Antônio Motta (2004) e outros tantos antropólogos brasileiros que se dedicaram ao tema.

Os cartões postais foram poderosos instrumentos de trocas sociais que moldaram não apenas as regras de amizade entre rapazes e moças em nossas cidades de outrora, mas orientaram seus códigos de namoro e de noivado, para finalmente conduzi-los ao casamento e a formação de suas famílias de procriação. Numa época em que a cidade de Porto Alegre há pouco despontava como uma metrópole com seus primeiros prédios publico de vulto, suas primeiras praças, os cartões postais expressavam formas de sociabilidade entre moças e rapazes que garantiam a preservação da honra da jovem, cuja conduta deveria se pautar pelo recato e o pudor nas suas relações na esfera publica.

As correspondências entre Dudu e Mariquinhas, afora alguns cartões de paisagem, são geralmente fotos de estúdio que recriam pequenas cenas com a figura da mulher como central, seu rosto, seus gestos e posturas. Fotografias de corpo inteiro ou não, as personagens dos cartões são essencialmente femininas ressaltando-lhe no rosto o ar de contemplação e o olhar vago, na postura corporal os gestos das mãos e dos braços geralmente posicionados discretamente ao longo do corpo, apoiando o queixo ou sobre o braço de uma cadeira como forma de construir uma figura angelical, que ao mesmo tempo, coquete, se esquiva do olhar do fotografo.

Importante ressaltarmos que uma boa parte dos cartões da coleção traz artistas e atrizes de teatro e de opera famosas na Europa. O zelo pela própria moral da época sugeria que estas mulheres autônomas, com uma vida profissional própria e mestras no exercício da vida publica retratadas por fotógrafos serviam igualmente de modelo para a

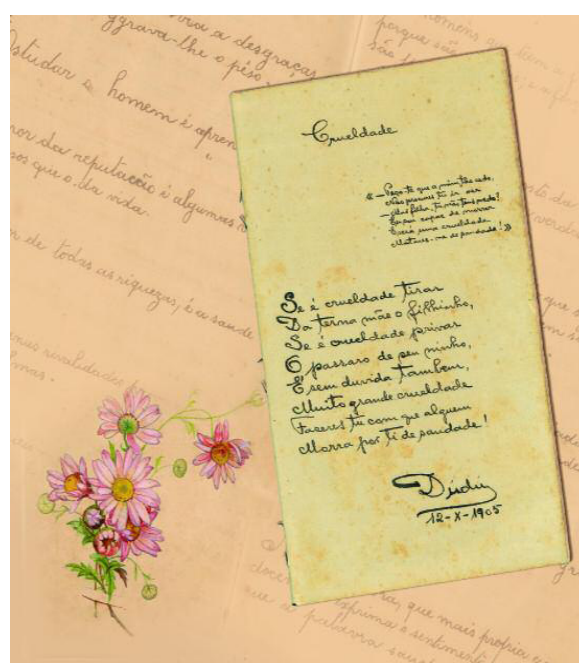
divulgação dos penteados, adornos e vestidos da época, aproveitando as formas de sociabilidade envolvendo a troca de postais como espaço de divulgação e propaganda da moda para as mulheres das classes mais abastadas.

Os cartões postais revelam, assim, a finura de modos, expressões e costumes que jovens das camadas mais abastadas da cidade cultivavam como forma obrigatória de expressão de seus sentimentos e emoções sobre as atrações ao sexo oposto, a amizade, a felicidade, enfim, a vida.

Os cartões postais situam-se como elemento fundamental do flirt e do "fazer a corte" das táticas e das astúcias da díade enamorada encontrar suas formas de manifestar seus sentimentos para o ser amado, originando-se desta correspondência um lento processo de entrosamento entre os amorosos que os conduzia do namoro ao noivado, culminando com o casamento. Reunindo numa complexidade 
inúmeras das expressões da cultura (a moda, a arte, a escrita manuscrita, crenças, etc.) os motivos e temas que eram fotografados, desenhados, pintados ou impressos nos cartões postais formam um rico mosaico de imagens através das quais as pessoas compartilhavam entre si seus afetos e sentimentos mais íntimos.

O "namoro à antiga" como as regras de namoro na contemporaneidade conformam uma unidade cultural, pois tratam das normas de relacionamento não só entre indivíduos e grupos, mas dos códigos de emoções, das regras morais, dos critérios de valor, da orientação afetiva que as presidem. Jovens de ambos os sexos trocam cartões entre si tanto quanto deles se valem para iniciarem correspondência com o sexo oposto, gerando-se dela toda uma rica rede social, sempre é bom lembrar, num centro urbano com poucos espaços públicos de sociabilidade, ainda sem luz elétrica, sem telefone e sem toda uma rede de transporte publico que ligasse o centro da cidade com seus arrabaldes.

No interior de uma forma de vida urbana em que os espaços masculinos e femininos de separavam em seus traços, com elementos e componentes distintos - o homem desafiado a ocupar o espaço da rua, dos cafés, dos prostíbulos e dos teatros, a mulher constrangida a vida domestica, as idas a igreja, a visita a casa de parentes, aos serões e a alguns poucos bailes, acompanhadas de homens da sua própria família -, estudando em escolas separadas, sob os olhares vigilantes de vizinhos e dos familiares, as formas de sociabilidade entre jovens de ambos os sexos estava envolta de uma aura de mistérios e fantasias.
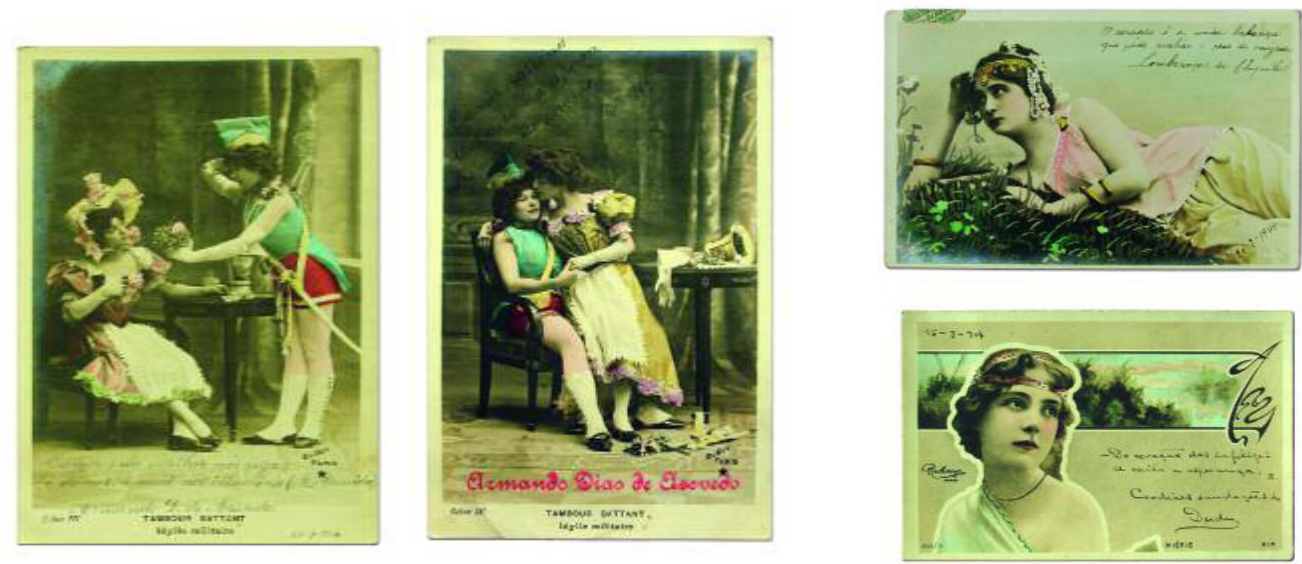

Principalmente entre rapazes e moças, numa tal atmosfera, a troca de cartões postais, assim como a troca furtiva de bilhetes e palavras em passeios ocasionais na praça cumpriria uma parte importante do processo de aproximação entre os sexos numa época em que toda a donzela deveria ter sua honra protegida de maledicências de boatos, para não acabar sendo considerada uma jovem de "vida airada", sendo seduzida pelas tentações da carne e do pecado.

Do namoro ao noivado, assim como do noivado ao casamento havia todo um protocolo a ser cumprido que implicava o flirt, o "fazer a corte", o namoro, quando o pretendente era então aceito pela jovem e pelos pais, indo visita-la em sua casa, em horas e dias determinados, geralmente sob o olhar atento de uma "tia" ou de empregadas especialmente orientadas para não deixar o namoro passar dos limites dos bons costumes, como era o adequado a uma boa "moça de família". 
Não se precisa comentar que a desonra de uma jovem, na época, implicava a desonra da própria familiar, moralmente atingida no caso de um "mal passo" de uma jovem, portanto, os cartões postais representavam uma regra de etiqueta que cumpriria sua função de escolha de cônjuges no interior de uma rede social no sentido de encaminhar os jovens para um determinado tipo de compromisso merecedor de confiança de suas famílias e amigos.

Importante lembrarmos que os cartões postais trazem os pensamentos escritos do remetente, não sendo colocados em envelopes, o que permitia um controle social dos pais sobre as formas de expressão dos sentimentos e das emoções de suas filhas em relação aos seus amigos e amigas tanto quanto aos seus pretendentes.

Do namoro ao noivado, não se poderia ter um intervalo de tempo muito longo, para não ocorrer o risco de o pretendente ser mal-falado, acusado de não ser alguém "mal-intencionado" e de estar enganando a jovem e sua família. Por outro lado, este tempo também não poderia ser curto para que não se pense que a jovem havia sido uma pessoa "fácil". No padrão urbano tradicional, o namoro oficial permitiria aos jovens enamorados as conversas de portão e de janela, a vista de todos e sob o consentimento da família da moça.

Do noivado oficial, resultante do pedido e do sim do pai da noiva, ao casamento, podemos dizer o mesmo: não poderia ser longo, nem breve. No primeiro caso, estaria comprometendo o futuro da jovem, num compromisso sem perspectiva futura para ela, já que o casamento, os filhos e o lar e que, segundo os padrões da época, representavam a razão de existência de toda a mulher; no segundo, as "más línguas" suspeitaria de uma gravidez indevida por parte dos noivos tendo em vista o ar "apressado" que daria origem ao matrimonio.
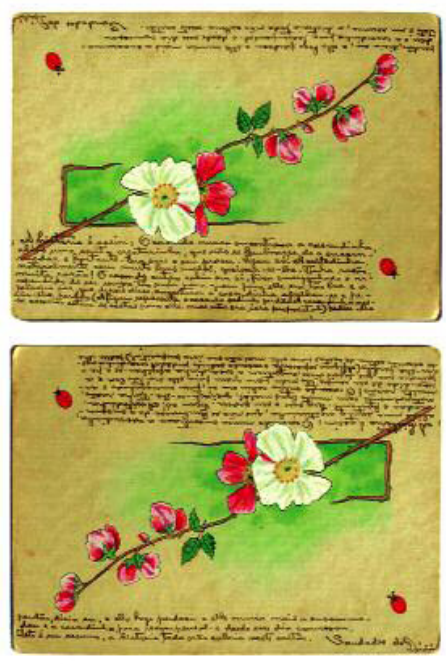

As leituras atentas dos cartões trocados, primeiramente, entre Dudu e Mariquinhas deixam transparecer claramente muita das fases de interação deste processo que conduz dois jovens da relação de amizade ao namoro, ao noivado e finalmente ao matrimonio e traz as marcas do amor romântico, ainda que orientado pelas exigências das obrigações morais das tradições patriarcais tão características da formação da família na sociedade brasileira.

Escolhemos uma linda série de 2 cartões encaminhados, todos eles, em 04 agosto de 1904 por Eduardo Marques Junior para Maria Angélica Casado, em que inicia a correspondência agradecendo-lhe a série de postais que ela lhe havia enviado, lhe retribuindo com postais que não se tratam de uma série. No primeiro, temos a foto realizada em estúdio de uma artista francesa, posando num cenário que procura retratar um parque com luxuosa e sofisticada roupa de passear, sombrinha rendada e chapéu adornado com penas de pavão. A ar coquete da artista, o olhar e sorriso por sobre os ombros, como se tivesse sido interpelada por um passante (o que olha o cartão) insinua o que Simmel denomina (em seu ensaio sobre a coqueterie) os encantos espirituais e os encantos físicos na figura feminina como fonte do despertar do prazer e do desejo, do dizer o sim e do dizer o não, ao mesmo tempo entrega e 
recusa. Nos dizeres a frase: De posse de teus cartões agradeço-te penhorado o Dudu. No mesmo dia, Dudu endereça outro cartão de agradecimento, destacando um dos cartões em particular (Muito minoso aquele cartão de leque!), mas que percebe ser este um gesto indelicado que ele corrige logo a seguir, comentando que os outros cartões como os recebidos da irmã de Mariquinhas, Othilia, também era mimosos: $O$ outro assim como o de Othilia, não o são menos.

Iniciamos aqui com a serie de seis postais encaminhados por Dudu para Mariquinhas no mês de julho de 1904, cada um deles referido a um dia da semana, do dia 25 ao dia 31. Trata-se de uma sequência de cartões resultado de fotos de estúdio, narrando a chegada de um caixeiro viajante numa estalagem e seus jogos de sedução para com a empregada do local que o atende. O personagem do caixeiro é representado por uma mulher em trajes de homens e a seqüência narrativa da série aborda o tema clássico dos jogos de sedução entre um homem e uma mulher do povo, cujas intimidades e caricias contrastam com a necessária reserva da alma que o amor burguês, romântico exige, ou seja, do prazer na intimidade em oposição a entrega total as alegrias eróticas mais "substanciais", nos termos de Georg Simmel (1934).

Passamos aqui a descrição da serie como forma interpretativa do jogo que as imagens dos cartões realizam com as escritas cuidadosas de seu remetente. No primeiro cartão tema a fachada de uma estalagem, cujo nome, não por acaso é "A la Belle", provavelmente aludindo a uma cena no interior da Provence, na França, pois ambos os personagens aparecem em trajes típicos da região rural deste país. Acompanha este cartão um agradecimento a amiga e o envio da série como contraprestação "modesta" de outra que recebera dela (25-07-1904: Mariquinhas, retribuo ao teu mimoso cartão com uma modesta serie cujo primeiro momento é este. Saudações cordiais do Dudu).

No segundo, temos o caixeiro-viajante sentado à mesa, sendo observado pela jovem garçonete da estalagem, e ele com o olhar cúmplice para o fotografo que, na posição de quem esta de posse do postal, observa a cena armada diante de si. A escrita alude aos dramas de um desejo secreto que por permanecer no silencio corre o risco de não se realizar (26-07-1904): Quando aspiramos alguma causa, atormenta-nos o receio de não a conseguir, mas, se a conseguimos, é o receio de perdermos que nos atormenta. Saúda-te, o Dudu.

O terceiro cartão traz a jovem empregada da estalagem saindo para atender o jovem comerciante, ambos cruzam-se olhares, o fotografo como personagem da estória desaparece para dar lugar ao naturalismo da cena. Mais um dia se passa (27 de julho) e o remetente tem mais palavras a dizer a amiga Mariquinhas: Quem ama verdadeiramente suportaria sorrindo as tormentas do inferno, para ter a ventura de ser amado. Saudações do Dudu. Inicia-se o tormento de uma escrita que reluta em revelar seus sentimento mais íntimos a amiga os quais irão transformá-la em alguém especial no interior de uma rede de colecionadores, ou seja, na pessoa objeto de seu amor. O cartão seguinte, traz o avanço na relação de conquista e sedução do jovem comerciante com a empregada da estalagem. Ele apresenta sobre a mesa os tecidos que traz consigo a jovem e esta parece encantar-se com elas. Os dizeres na série dos cartões avançam lentamente para a expressão zelosa dos sentimentos, enfrentando uma luta entre a continência, o recato e a manifestação prematura de sua paixão (Muitas vezes o amor é o único elo que nos prende a vida. Segue-se o outro postal (28 de julho) onde a cena entre os amorosos evolui abertamente dos jogos de sedução para o "fazer a corte". A postura e o gestual da jovem apresentam uma cena de intimidade com o jovem recém chegado, ela quase sentada na mesa, ele próximo a ela, inclinando sedutoramente, com 
gesto de solicitação de um beijo na face. Os tecidos abertos sobre a mesa assim como sua valise aparecem em segundo plano. No cartão do dia 29 de julho, os dizeres do remetente anunciam sua esperança em ser correspondido em seus sentimentos pela amiga agora quase transformada numa totalidade indiferenciada de mulher objeto de desejo e de amor: Quando na viagem da vida nosso guia é a esperança e o ponto almejado, objeto de nosso amor, afrontamos sorrindo os maiores obstáculos. Afetuosas saudações Dudu (sem o "do").

A seqüência culmina com os dois últimos postais da série, de 30 e 31 de julho, e onde os jogos amorosos entre os jovens retratados nos cartões. Primeiro os jovens, ambos inclinados sobre a mesa que os separa, beijam-se, e não por acaso os tecidos e valise do colporteur não fazem mais parte do cenário (A constância é companheira inseparável do verdadeiro amor. Saudades Dudu, novamente sem o “do"), E, no ultimo, vemos que o jovem caixeiro-viajante finalmente conquista a sua amada que, sentada no seu colo, tem a cabeça apoiada no ombro do jovem sedutor, que já não esta mais usando o seu chapéu. Finalmente os tecidos reaparecem sob a mesa assim como um pedaço da valise insinua a displicência do caixeiro viajante com as suas intenções iniciais de venda no vilarejo local (Mariquinhas com este finaliza-se a serie que com o maior prazer te dediquei. Sinceras saudações do Dudu, retorna o "do").

A troca de cartões postais que vemos aqui ocorrer entre Dudu e Mariquinhsa se revela uma instituição no interior da vida urbana das grandes cidades brasileiras, como nas grandes metrópoles da Europa. Tratava-se de uma verdadeira moda a troca de cartões, geralmente importados, e que tinham por finalidade para aquele que entrava no circuito de tais trocas configurarem coleções formadas por séries de cartões que narravam as mais diversas estórias através de fotografias realizadas em estúdios retratando cenas com personagens fíctícios em estúdios, sendo que muitos destes cartões eram posteriormente pintados e trabalhados em alto relevo.

Tratava-se certamente de uma moda que somente poderia ser adotada por jovens de famílias abastadas que poderiam adquirir tais cartões em lojas de produtos importados, pagando-os " à peso de ouro". Certamente conseguir completar uma série de cartões e enviar tais cartões a amigos e conhecidos representava um alto status e prestigio do remetente na rede daqueles que se correspondiam. Pensar a compra destes cartões na Porto Alegre de fins do século XIX como parte dos modos de vida burgueses se introduzindo na vida urbana local, antes mesmo da industrialização da cidade, se torna um grande desafio.

Os cartões postais tratam de hábitos de estratos superiores da sociedade portoalegrense em seu processo de adoção aos requintes de estilos da vida européia e apontam para as marcas de distinção entre jovens de uma mesma classe social se pensamos os locais de venda de produtos importados na cidade, as pessoas que os freqüentavam e a origem social daqueles que deles podiam usufruir.

Lembremo-nos que Dudu morava na rua Mal. Floriano, no 248, no bairro Centro, na época a área central mantinha seu ar aristocrático construído pela presença de sobrados e casas onde moram as famílias mais abastadas, das praças da Matriz e da Praça da Alfândega onde despontavam os principais prédios públicos da cidade. Mariquinhas, morava com sua família, numa das alas do Hospício São Pedro, no bairro Partenon, instituição que seu pai, um militar, tinha sido designado para supervisionar.

A tradicional troca de cartões postais expressa aspectos importantes da estrutura da vida familiar das camadas mais abastadas de Porto Alegre, no inicio do século XIX e das transformações que se anunciam para a construção do feminino na vida urbana 
local. Recordemos que a Porto Alegre da época do romance de Mariquinhas e Dudu ainda não era a Porto Alegre da belle époque do footing da Rua da Praia, das ruas do comercio chic de moda, das confeitarias, das sorveterias, dos jardins, das alamedas e dos parques, dos matinés e dos cinemas, onde o primeiro "comercio de olhares" aparentemente casuais ocorriam e as primeiras aproximações aconteciam entre os jovens. Entretanto algumas modificações já se anunciavam nas formas de sociabilidade nos espaços públicos da vida urbana local.

Substituindo-se pouco à pouco as técnicas prosaicas das antigas serenatas, dos recados e bilhetes enviados furtivamente por crianças e empregadas, surgem novos espaços de trocas sociais entre os jovens e os enamorados como os passeios, as procissões, as missas, as quermesses que com os inicio dos bondes e da luz elétrica vieram a transformar as formas de socialização do amor, seguidos da publicação de livros específicos sobre os gestos e maneiras de fazer a corte (o namoro de luvas de pelica), onde a linguagem das flores florescia em toda a complexidade de seus simbolismos, a rosa, o lírio, a tulipa, o narciso cada um com seu significado a ser decifrado pelo ser amado.

O tema floral e campestre é uma das características da sequência de postais encaminhados por Mariquinhas em fevereiro do ano de 1905 para Dudu onde podemos observar maior intimidade entre ambos, provavelmente fruto de um processo de namoro que em transição. O primeiro retrata uma cena com duas meninas ao redor de um tronco de arvores, rodeada por flores. Uma delas esta apoiada no tronco de uma arvore, com a cabeça voltada para o lado esquerdo, olha sorrindo para o lado oposto. A outra, mais velha, tem sua mão apoiada no tronco da mesma arvore que aparece quase encoberta por flores, a observa quase como se a estivesse vigiando. Em ambas as fotos as figuras femininas, de perfil, não aparecem de corpo inteiro. $\mathrm{Na}$ escrita a remetente refere-se ao envio dos postais como parte de uma promessa feita ao destinatário (Este é o primeiro numero da serie que eu te prometi. Saudações Mariquinhas).

No postal seguinte as duas meninas aparecem abraçadas. A mais velha aparece de perfil, olhando a outra menina, menor, envolvendo-a num abraço. A menina menor, em pose frontal, olha o fotografo. Ambas encontram-se ao lado do mesmo tronco de arvore que está envolto em flores, o cenário se parece agora mais com um jardim. $\mathrm{O}$ afeto e a cumplicidade entre as figuras femininas parece ser o forte deste cartão, certamente como expressão das inclinações interiores da remetente ao jovem destinatário da correspondência, mantendo o desejável recato e pudor para com ele uma vez que os atributos das figuras representadas nesta série de postais, mais especificamente, não comprometem o ser apaixonado (Não há razões que destruam o verdadeiro amor. Mariquinhas).

Segue-se outro cartão com uma simples escrita - Saudades, Mariquinhas - no qual as figuras das duas jovens estão olhando o fotografo, ambas sorrindo. Uma delas, de perfil, sentada numa cadeira cujo espaldar acomoda um cesto de flores e a outra, de frente, encostada nela e com o corpo apoiado neste espaldar. E, por fim, encerra-se a série com o ultimo postal onde a remetente explicita o prazer que representou para ela o cumprimento de sua promessa de troca de cartões com o destinatário (Este é o ultimo numero da série que tenho muito prazer de te enviar. Mariquinhas). O postal traz novamente as meninas conversando ao redor de uma cesta de flores, ao fundo aparecem ainda mais flores. Uma das jovens apoia a cabeça sob o vaso, sorrindo e olhando para baixo, a outra menina, sentada a sua frente, olhar baixo sobre a cesta de flores que esta entre elas, tem na mão uma flor da qual sente o perfume. Ao se ler atentamente os 
postais e se observar a escolha da série, sentimos, por detrás do tratamento cerimonioso, um grau de sofrimento no coração inquieto de uma jovem a declarar-se timidamente ao seu amigo intimo, respondendo provavelmente a seus galanteios.

Do ponto de vista dos modos de declarar-se a amada, a correspondência através dos postais e principalmente algumas de suas séries permitiram ao rapaz diante de uma moça o exercício de algumas táticas de sedução, sem, entretanto, expô-los ao controle das regras e dos padrões morais em uso.

Interessante trazermos para o leitor o fato de que no conjunto das coleções dos cartões postais guardados carinhosamente por Mariquinhas ao longo de todos estes anos, e que chegaram até nós, temos aqueles encaminhados a ele por um admirador um tanto quanto descontrolado para as regras da época, denominamos a este admirador de $o$ ardente Armando e cujas palavras recolocamos abaixo: $O$ amor pela mulher nos cega; o de nossa mãe nos ilumina. (A. Almeida) Armando D. de Azevedo.

Este cartão como o que seguirá trata-se de uma série através das quais se representa em fotos montadas em estúdios os amores de jovens militares com suas cortesã. Interessante que em postais deste tipo temos mulheres representando os papéis dos personagens masculinos. No postal, aparece um soldado totalmente fardado que oferece flores a uma jovem sentada. O jovem soldado segura seu chapéu com a mão direita, com a esquerda oferece o bouquet e tem o corpo inclinado para a jovem senhorita que, sentada com a mão esquerda apoiada na mesa, o rosto inclinado sobre o ombro direito, olha para ele, com a mão esquerda em deslocamento para pegar as flores ofertadas. A jovem esta vestida com luvas e chapéu adornado de flores, por sobre o vestido um avental. O tema trata do amor pela mulher amada e as ameaças da cegueira do desejo em contraponto ao amor da mãe, o amor sem paixão carnal.

$\mathrm{Na}$ seqüência da série $o$ ardente Armando temos o envio de outro cartão da mesma série intitulada, Idílio militar (Idylle militaire), com os seguintes dizeres: $O$ amor nasce nos olhos, cresce na esperança e morre no coração. Este cartão não traz a assinatura de Armando, mas seu carimbo. No postal temos agora o soldado com seu fardamento incompleto, em posição de relaxamento e repouso, sentado numa cadeira, com a jovem agora sentada em sua perna esquerda e segurando com a mão direita a sua mão esquerda. A jovem esta beijando sua fronte e tem seu braço direito envolto em seu pescoço. Ao lado a mesa onde estão as luvas do soldado, encontramos o vaso que antes estava sob a mesa encontra-se caídos no chão, e junto a ele as flores e a espada espalhadas próximas a ele. Torna-se evidente que entre este cartão e o anterior da série, o arrebatamento da paixão entre os personagens desencadeou uma cena de amor entre ambos que a fisionomia e as expressões corporais de ambos aludem. Os dizeres escritos pelo ardente Armando sobre o amor nos olhos e sua morte no coração fala deste percurso corporal da paixão e do desejo anunciado a Mariquinhas, servindo de sinais para a destinatária dos postais como forma de deduzir as intenções amorosas do remetente.

O caráter pessoal e intimo dos escritos que acompanhavam o cartão postal compunham um todo com os costumes e as tradições de um círculo de convívio social, segundo certas localidades (geralmente trocados entre jovens de camadas medias urbanas, letradas), de laços de família (era usual parentes participarem de uma mesma rede social de correspondência de postais) assim como de posições sociais (evidenciada pela raridade que os postais representavam para o consumo da época)

Por outro lado, os pensamentos escritos nos cartões e nas imagens do feminino que eles divulgam trazem em si o contraponto entre a moça casadeira à moça caseira, 
temos a jovem que domina a "arte sutil de pisar na rua", que não teme os bonde, nem as carruagens e a jovem "prendada e recatada", envolta numa atmosfera de pureza virginal, quase infantil. Na coleção temos muitas as imagens de tais tipos femininos cujas expressões corporais e faciais contrastam com a atmosfera de recato e delicadeza dos pensamentos escritos que o bom costume sugere para o caso da expressão de caráter pessoal e intimo das emoções e dos afetos que nutrem as relações entre rapazes e moças.

A imagem feminina projetada pelos cartões postais trocados entre os jovens, na "ubiquidade da fotografia", traz sempre atrizes ou artistas famosas, em sua maioria, do teatro e da opera parisiense, com elegantes trajes, chapéus, penteados e os adornos que faziam o "bem-vestir" europeu, com expressões faciais e corporais sedutoras e olhares lânguidos. Tais tipos femininos, detentoras dos "artifícios de toilette", que circulam na vida mundana europeia, são transladados para uma cidade que se moderniza como Porto Alegre e se transformam em verdadeira mania.

Certamente os tipos femininos retratados em muitas das figuras dos cartões postais intercambiados não são figuras de retóricas, veladamente sugerem os sentimentos, os estados emocionais e até mesmos as ideias daqueles que os compram e para quem são dedicados. Uma série de cartões enviados por Dudu a Mariquinhas é expressiva destas figuras de retóricas. A correspondência não tem data, o que prejudica saber em que faze das trocas de pensamentos íntimos encontrava-se os dois enamorados na época. Percebe-se que a tema dos cartões e a escrita perderam parte do tratamento cerimonioso e apresentam referencia constante a uma linguagem carinhosa e ao mesmo tempo ardentemente apaixonada por parte do ser amoroso.

Os cartões contam a estória de alguns soldados que sitiados no interior de uma casa resistem bravamente à batalha contra os inimigos que desejam toma-la. A alusão a casa, a morada como corpo e o coração da amada e os soldados, representados por crianças fardadas, com armas de brinquedo, como a alma que habita este corpo, em luta para defendê-lo não é exagero se pensarmos as próprias escritas que acompanham cada uma desta riquíssima série de postais. Primeiramente, é interessante a descrição densa das cenas retratadas da série de postais, intitulada Les dernières cartouches (Os últimos cartuchos).

A sequência de cartões endereçada por Dudu a Mariquinhas, sem precisão de data, começa com um postal (fotografia de estúdio) que representa uma cena de uma batalha, vista do interior de uma casa sitiada, um grupo de soldados, representados por crianças vestidas com figurinos de soldados, portando armas de brinquedo, resistem a sua invasão. Um das crianças, em pé, esta ao centro de sete crianças, mãos na cabeça, agarrando os cabelos, em pose melodramática de total desespero, outra mais abaixo, ajoelhada, em posição de desanimo, arma ao lado. As outras crianças-soldados em posição de ataque diante das vidraças de uma janela. Interior da cidadela em desarrumação (A ausência é uma flor cujo perfume é a saudade. Saúdo-te o Dudu). Próxima cena representa quatro dos soldados resistindo com armas em punho, um soldado ao centro que olha o fotografo e coça a cabeça. Atrás dele mais soldado em gesto de desespero, um dos braços está erguido com o punho fechado e no outro a mão segura uma espada. Ao redor deles mais três soldados sentados ao chão, abandonam a batalha, sendo que um deles encara o fotografo. (A vida sem esperança seria árido deserto sem uma gota d'agua, sem folha verde. Dudu). Segue-se a cena dos soldados agora durante a trégua da batalha. Três dos nove soldados-crianças estão em pé, outro está ajoelhado. Outros três soldados estão sentados no chão, um deles fita o fotógrafo; um soldado acocorado faz curativos em um de seus companheiros. Outro soldado 
sentado sob um banquinho. Dos 9 soldados apenas dois insistem em lutar e empunham suas armas, o restante aguarda o final da luta. Um dos soldados sentados encara o fotografo (A promessa, irmã da esperança, é uma flor que embalsama a alma. Saúda-te cordialmente o Dudu).

Os postais seguintes retratam os soldados retomando a luta e sua capitulação por falta de "cartuchos". No penúltimo, cinco dos nove soldados reassumem seus postos e apontam suas armas para a janela da casa. Outro soldado apoiado a porta da central, apóia sua mão na fronte em situação de desespero, olhando para o fotógrafo. Dos outros 3 soldados, dois estão acocorados, a espera de sua fez de entrar na luta, e um esta encostado na parede, com a arma nos joelhos, olhando para cima (Os sonhos são nevoeiros encobrem as incertezas do porvir. Souvenir Dudu). O ultimo cartão da série apresenta apenas dois soldados empunhando suas armas em frente à janela. Dois soldados, um recostado e outro deitado de costas, parecem estar mortos. Outros dois soldados em pé, sendo que um observa os seus companheiros de luta, na frente da janela. Os três últimos dos soldados, um está sentado ao chão e dois acocorados, aguardam o fim dos acontecimentos. As armas estão ao lado, assim como pedaços de tecidos usados para os curativos (A fé e a esperança são duas emanações de Deus. Saudades Dudu).

Vemos nas escritas de Dudu para Mariquinhas nos cartões que ele fala de suas inclinações amorosas a jovem amiga, valendo-se de frases e dizeres elaborados por poetas. Sabemos que Dudu tinha por hobby escrever frases, dizeres e versos de poetas famosos em um pequeno livro azul que foi achado entre os cartões guardados por Mariquinhas ao longo de todo este tempo. As escritas dão conta das diferentes táticas e astúcias empregadas para declarar-se a jovem moça por quem ele nutre admiração e amor. Da ausência da pessoa amada ao sentimento de saudade, da alusão esperança como alimento da vida, passando pela constatação de que um ato de promessa é o que dá sustentação à vida do espírito e pelo reconhecimento dos perigos das ilusões diante das incertezas da vida, o galanteador Dudu conclui, finalmente, pela presença divina na expressão de seus sentimentos íntimos em relação à Mariquinhas. De saudações repetidas no final de cada postal da série, chegamos ao final com a simples frase confidenciada: saudades Dudu.

Como esta série aqui resumida, as imagens contidas nos postais que os jovens se utilizam para se corresponder sugerem sempre esta atmosfera de inocência retratada nas figuras de crianças e entre crianças e jovens meninas em atitudes de namoro, acariciando-se, trocando olhares e caricias, geralmente num cenário onde as flores, as rendas e os tules predominam.

Diferentemente desta série que reúne a correspondência entre jovens de sexos diferente, na coleção dos cartões de Mariquinhas encontramos postais trocados, sem grandes constrangimentos, entre jovens do mesmo sexo, como expressão da atmosfera de camaradagem e da amizade entre ambos. As imagens contidas nos cartões e o teor das escritas nos permitem pensar as normas e os princípios socialmente estabelecidos e culturalmente pautados, na época, para as formas de sociabilidade no interior de uma mesma categoria de gênero e como elas eram mais flexíveis não sendo encaradas como tendo propósitos específicos no sentido afetivo-sexual, como poderíamos atribuir hoje a semelhantes postais.

Neste sentido, as formas de sociabilidade entre pessoas do mesmo sexo, na época, permitiriam confidencias a partir das trocas de cartões postais entre pessoas do mesmo sexo que, nos dias atuais, poderiam sugerir relações amorosas homoeróticas. 
Uma das séries de cartões com estes traços é aquela de cartões enviados por Nico a seu amigo de Dudu. Vamos trazer aqui, em especial, dois cartões com cenas fotografadas em estúdio, aliás, como os outros são postais, cartões importados do estrangeiro, e que narram cenas da corte e do flerte de um homem com uma mulher. O primeiro deles traz a imagem de um jovem recostado a observar uma jovem distraída fazendo crochet, num jardim, provavelmente trata-se do inicio de um flirt entre ambos e o cenário alude a ambiência de um recanto de uma casa de campo, na tela pintada ao fundo aparece um vale com um rio serpenteando-o; no cartão o amigo alerta o amigo Dudu: Não rias de quem chora porque mais tarde podes ficar assim. O segundo postal traz outra cena fotografada em estúdio. Uma jovem na porta entreaberta recebe um jovem moço recém chegado a sua casa, com um sorriso, com os seguinte dizeres: Recomendo-te

(ilegível) que estava muito boa e não andavam mais atacando, assim que pode ir.

Outro exemplo de regras de camaradagem e amizade entre pessoas do mesmo sexo a que aludimos anteriormente é a sequencia de postais trocados entre as amigas, Dedéa e Mariquinhas, tem por tema a sinceridade e o amor, a amizade, a caridade e o despojamento de si, enfim assuntos do coração em que a alma feminina é comparada a alma de uma criança por sua pureza e ingenuidade. O primeiro cartão traz os dizeres: $O$ amor não se define - sente-se. Saudades de tua amiga Dedéa e retrata duas meninas num cenário que recria um quarto de criança, com uma lareira ao fundo, sob a qual estão um porta-retratos e vasos. Sob o chão há um tapete e um berço de bebe coberto com mosquiteiro, ao lado dos quais as duas meninas encontram-se brincando. Perto delas há uma saco de roupas aberto. Uma das meninas esta sorrindo, olhando para o canto esquerdo superior da foto, a outra criança esta com as duas mãos no seu braço esquerdo, como se estivesse ajustando a manga do vestido da amiga.

O segundo cartão tem o título Les Baisers (Os beijadores) - Beijo da amizade, trazendo as seguintes palavras: As lagrimas exalam-se de dois modos: uma que assomam-se aos olhos, outras que caem no coração e queimam esta bela flor da mocidade chamada esperança, Conheces este pensamento? Beijo-te tua amiga Dédea. Trata-se de um postal que apresenta dois meninos vestida de querubins com asas, flores na cabeça, cabelos encaracolados e panos enrolados na cintura. Um dos meninos, meio de perfil esta ajoelhado sob uma perna, mão direita no joelho direito, em frente ao outro menino, em sua frente, totalmente de perfil, lhe segura as duas bochechas com as mãos, tem o rosto e corpo inclinado de quem vai dar um beijo no outro. A tela de fundo não revela nada do lugar onde a cena se passa. Diferente dos outros se trata de um belíssimo cartão trabalhado em alto relevo.

O terceiro postal enviado pela amiga a Mariquinhas pertence a uma série intitulada Ames es Enfants (Alma de crianças). No cartão há um verso, em francês (Par quel chemin es-tu venue, ô ma pauvrette?. Mais par le quel là-bas, qu'il nomment la Chevrette. Tu n'y passeras plus... dis, Claudine, as tu faim? Prends-vite ma tartine et ces fruits, tends ta main. Noëlle de Nivette) que explica a estória entre as duas meninas: Duas jovens meninas conversam. Uma das meninas, sentada num banco, no interior de um bosque, com um cesto de flores, encontra uma outra jovem menina, pobre, que por ali passa, e lhe oferece o que comer, a torta que trazia consigo alem de um ramalhete de flores. A menina mais pobre estende a mão em direção a torta que a outra menina que oferece. Os olhares dos personagens esta orientado para a ação que ali se passa. Um outro verso, entretanto é escrito para a amiga: Parte cartão venturoso, A Mariquinhas vai ver. Dize que eu fico chorando. Por ir também não poder. Dedéa 
Estas correspondências, como as anteriormente apresentadas trocadas entre Nico e Dudu, revelam que as imagens dos cartões postais trocados entre pessoas alem das escritas neles contidas conversam entre si como um forma metafórica de conversação entre ambos, aludindo a algumas situações por eles compartilhadas. Por outro lado, os cartões postais trocados por Mariquinhas e Dudu com seus amigos do sexo opostos e as series de cartões trocados entre os dois revelam estas formas de aproximação e de expressão do desejo do compromisso típicos do amor romântico na classe burguesa portoalegrense, segundo as quais cabe ao rapaz a provocação ao namoro entre inúmeras candidatas, enquanto as moças lhes restam escolher apenas um entre aqueles que lhe fazem a corte, já que elas não podem se oferecer aos rapazes.

Voltando-se, assim, novamente para à Porto Alegre do inicio do século XIX e a rica correspondência entre Mariquinhas e Dudu e, em especial, às formas de sociabilidade que elas promovem no sentido de colocar em contato rapazes e moças das camadas mais abastadas desta cidade, vemos a troca de cartões como tecendo uma caso de amor no interior de uma rede social de amigos. Como já ensaiamos à pouco, através dos postais trocados e dos pensamentos que neles estão escritos podemos acompanhar o lento processo de ação do sentimento amoroso singularizando cada um dos jovens desta díade no interior de uma rede de amigos, até finalmente reuni-los como marido e mulher, pai e mãe no âmbito de uma família.

Os cartões trocados entre eles sugerem, num espaço de tempo que vai de 1904 a 1907, um processo de descoberta mútua de dois jovens amigos que podemos considerar como sendo uma etapa preparatória para sua união conjugal futura. Ao se trocarem postais estes dois jovens vão progressivamente proceder as suas escolhas mútuas dentre outros possíveis parceiros no interior de sua rede social, diferenciando suas interações dos outros possíveis futuros parceiros. Da mesma forma, as trocas dos postais acabam por fixar os dois jovens como parceiros únicos no interior de uma díade amorosa a partir de uma rede social de amigos comuns, alem de conduzi-los progressivamente para os costumes do namoro, do noivado e do casamento, habituando-os aos papéis de marido e mulher e, posteriormente, de pai e de mãe como testemunham seus descendentes.

Através da troca de postais, vemos Dudu, ingressando na família de Mariquinhas, chegando a ser amigo de seu cunhado, Aristides provável facilitador dos contatos mais íntimos com sua irmã, e que seria, provavelmente, aquele incumbido de vigiar o comportamento de ambos. Este hábito usual de colecionar cartões postais entre a rede social de ambos responde as cautelas e protelações que orientam a aproximação dos rapazes para com suas amigas, através de relações de camaradagem e amizade, sem que sejam por isso sejam consideradas "mal-faladas". Vamos observar estes preceitos do "bom moço" numa sequência de cartões que o jovem enamorado envia a sua amiga, insinuando a presença de um sentimento de atração e afeto entre ambos o qual seria o grande responsável por retirar suas trocas de cartões da mera indiferença para situá-la no plano das relações amorosas. A serie se inicia com um cartão em que vemos uma menina surpreender uma jovem moça cosendo, sentado em um banco, com seu cesto de costura aos pés. O cenário pintado em tela mostra ao longe um percurso de estrada serpenteando os campos. A menina venda os olhos da jovem, parecendo ter com esta ultima uma grande intimidade. Na escrita, o jovem Dudu transcreve um pensamento: $O$ criador colocou a frente de nós um ente benfazejo, a esperança, e logo após assina com uma mensagem, Afetuosas saudações do Dudu.

No próximo cartão temos a mesma criança, agora com uma as mãos no bolso e outra apoiada no trinco de uma porta, subindo as escadas de uma choupana simples. A 
jovem moça ao seu lado, com feixe de feno e algumas flores, nas mãos, ao fundo um riacho e algumas arvores, ambas em trajes de camponesas, parecem ter sido surpreendidas, pelo fotógrafo entrando na morada. Seguem os dizeres: Quando somos felizes tudo é belo, tudo nos sorri. Dudu.

$\mathrm{Na}$ sequência, a jovem está sentada nas escadas da choupana, com flores no colo, olhando para a menina, que retribui o seu olhar e que sentada sob um feixe de feno tendo nas mãos um ramalhete de flores. Ao fundo identificamos o mesmo cenário anterior. A mensagem do cartão é simples, Dudu fala a Mariquinhas do amor verdadeiro como o sentimento que atribui uma alma ao mundo, eternizando-o: Quando o amor é verdadeiro dura mais do que a vida, porque acompanha a alma, a eternidade. Saúda-te o Dudu.

No penúltimo cartão encontramos novamente a jovem moça sentada no degrau da choupana. Ela esta distraída colocando flores no chapéu da menina que, recostada em seu corpo e sentada num monte de feno segue, com o olhar, os gestos de suas mãos da jovem. O jovem fala então das inquietudes do coração quando a pessoa enamorada descobre a possibilidade do sentimento amoroso chegar ao seu fim por uma desilusão, talvez de um amor não correspondido pelo ser amado: Quando somes felizes o que nos inquieta é o receio de que essa felicidade não seja duradoura. Saudações cordiais Dudu

Finalmente, no ultimo cartão desta série, a personagem da jovem está recostada no ancinho, sob um dos degraus de uma choupana, olha para uma menina que se despede dela por detrás de um portão de madeira, fechado. $\mathrm{O}$ gesto da menina com mão sob os lábios e o olhar em direção da jovem da ideia de um beijo "jogado", de longe, como forma de despedida. Os dizeres escritos imitam a imagem recriada no cartão, a despedida antecipa a saudade: Saudade - hera do coração, sempre verde e tristonha. Saudações do Dudu

Ressaltamos que as personagens do cartão, duas figuras femininas, uma jovem e uma criança, e o que elas vivem no interior da série dos postais, alude ao sentimento que Dudu começa a nutrir por sua amiga Mariquinhas, mas não compromete completamente suas relações de camaradagem, pois o conjunto desta série como um todo não explicitaria abertamente suas intenções de fazer lhe corte, necessitando-se para isto que ela decifrasse o código da mensagem enviada. Por outro lado, da parte de Mariquinhas, o retorno aos cartões de Dudu como a de outros rapazes lhe permitem uma troca afetiva com o sexo oposto sem parecer "assanhada" ou "oferecida". As escritas de pensamentos envolvendo sentimentos de ternura e até mesmo paixão entre rapazes e moças, mais do que entre amigos do mesmo sexo, sofrem os limites das normas morais de respeito e mútua confiança, todas as duas extensivas às famílias envolvidas nestas trocas sociais, dando-lhe, neste caso, legitimidade a estas correspondências.

As trocas de postais entre Mariquinhas e Dudu mais significativas se iniciam em 1904 perdurando até 1907, quando parece ter a amizade e a camaradagem entre eles resultado numa estória de amor. Entretanto, em 1903, já havia correspondência entre Othilia, irmã mais velha de Mariquinhas, e Dudu, o que nos faz pensar que as aproximações entre esta última e ele foram facilitadas pela rede social de sua irmã. Em 1904, os escritos numa serie de cartões postais enviados por Othilia a Dudu, anunciam uma possível relação amorosa frustada entre ambos, com a jovem progressivamente tomando consciência de que esta relação não evoluiria para um namoro entre ambos. Podemos pensar que Dudu poderia ter iniciado uma aproximação com Othilia e que, 
mais tarde, as trocas de cartões entre ele e Mariquinhas o teriam conduzido a unir seu destino a ela ao invés da irmã mais velha.

Segue abaixo, a sequência de cartões acima referida e que denominamos "a espera frustrada da corte"

1) (13-04-04) Com a paciência e a perseverança tudo se alcança. Othilia

2) (30-05-04) Examinai bem se o que prometeis é possivel e justo, a promessa depois de feita é irrevogável. Othilia

3) (27-07-04) O ciúme apaga a luz do pensamento e ofusca a razão e só deica ver as coisas pelo lado pior. Othilia

4) (02-08-04) A maior de todas as riquezas, é saúde da alma. Othilia

5) (10-10-04) Quem em Deus confia e espera, nunca desespera. Othilia

6) (12-09-04) Cordiais saudações, Othilia

7) (21-11-04) Sem o sorriso da esperanças, a vida é sempre triste. Othilia

Sabe-se que no séc.XIX havia todo um critério de idade para os jovens, homens e mulheres, ingressarem em redes sociais de amizade que os conduziriam ao namoro. As mulheres ingressavam em idade de namoro dos 15 aos 24 anos e os homens, geralmente mais velhos em torno de 5 anos, entre 20 e 29 anos, pois implicava que eles deveriam ter condições, após um tempo de namoro, casar e sustentar uma família. A escolha amorosa de Dudu recair sobre Mariquinhas ao invés de Othilia faz parte deste evidencia.

O medo do "ficar pra tia", na época, e a condição de solteirona era uma das grandes ameaças para a vida de muitas jovens que não achavam no casamento o seu lugar no mundo social. Cuidar dos sobrinhos, ajudar a criá-los, nos serviços da casa, no controle moral das novas gerações ( a figura daquela que "segura a vela") eram algumas das funções sociais femininas na família quando na grande metrópole não era dado as mulheres o direito de ter uma profissão.

$\mathrm{Na}$ época, entres as camadas sociais mais abastadas das cidades fazia parte das prendas de uma moça caseira a sua formação nas ocupações do lar, saber coser e bordar, fazer doces assim como ler e escrever. A cuidadosa escrita manuscrita nos cartões, a citação recorrente a versos e pensamentos de poetas, o rigor na estrutura gramatical das frases, tudo revelava não só a grandeza de espírito do remetente do postal, mas mencionava sua condição social aquele que o recebia. A troca de postais acaba por se revelar um critério de restrição a camaradagens e amizades entre rapazes e moças de estratos sociais diferenciados, um dos grandes riscos para o caso de namoro, noivado e casamentos entre jovens de origens sociais distintas, gerando-se incompatibilidades entre as condições individuais dos enamorados e de suas famílias de origem.

Neste contexto, em conformidade a família burguesa que se impunha ao modo de vida urbano em Porto Alegre, a correspondência entre Dudu, Mariquinhas e sua rede social de amigos e conhecidos revela que os postais trocados entre rapazes e moças, ainda que com residências distantes, acabavam por selecionar, no interior de uma rede social, personalidades semelhantes atitudes, padrões de comportamentos e preferências, atuando como fator de escolha de candidatos a união matrimonial no interior de uma mesma camada social.

Vejamos a seguir alguns dos cartões enviados por admiradores para Mariquinhas e que foram guardados junto com os postais encaminhados a ela por Dudu, seu futuro esposo, revelando a elegância que na troca de postais o "fazer a corte" representava. Um dos postais é um pequeno verso que brinca com o sobrenome da destinatária Mariquinhas Casado - e que não traz a assinatura do remetente, o que se supõe a 
identidade deste admirador ser do conhecimento de Mariquinhas e não necessariamente de seus familiares, nas mãos de que certamente o postal primeiramente iria cair. $\mathrm{O}$ primeiro postal é aquele que denominamos $O$ admirador secreto: Marquinhas Casado que solteira ainda esta. Tu te casas comigo, que feliz me fará . teu $F$.

$\mathrm{O}$ segundo, ao contrário, traz abertamente a assinatura do enamorado, alem de expressar abertamente sua inclinação amorosa pela destinatária: A gentil senhorita Mariquinhas Casado e a sua Exma família deseja sinceras felicidades, enviando este lindo cartão por achar em tudo parecido com a galante destinatária. Humilde admirador. Agenor Castilhos França

O prestação e contra-prestação de postais entre os colecionadores os obrigava a retribuir um cartão raro com outro mais raro ainda, por seu turno, destacavam um colecionador entre tantos outros por sua elegância e cortesia, alem das posses que lhe permitiam encomendar series inteiras de postais desejadas por toda uma rede social. Há, portanto, uma compatibilidade de condições sociais e a observância de determinadas regras na conformação das trocas sociais que as coleções de cartões postais instauravam impunham entre rapazes e moças de Porto Alegre do inicio do séc. XIX e que não poderia ser visto como parte de um estilo de vida generalizado, na época, a todas as camadas sociais desta cidade ou de qualquer outra no Brasil.

O teor dos pensamentos e dos versos escritos nos cartões, por seu caráter publico de leitura eram de tal modo escolhidos pelos rapazes para evitar se expor as jovens de sua rede social a situações embaraçosas moral e socialmente, o que levaria a moça ao ostracismo e ao desprestígio, já para o caso das moças tratava-se de procurar modalidades de escritas que anunciasse estilos de comportamento recatado de "moça de família", "moça de respeito". As inclinações afetivas, a sensibilidade no plano dos sentimentos, os gostos, os prazeres, os desejos íntimos eram temas diversos que estavam presentes nos postais trocados, sendo estas trocas de "confidencias" o próprio processo que conduzia os colecionadores de ambos os sexos a escolherem-se segundo a compatibilidade de interesses e valores ético-morais de cada um, e que conduziriam ou não a uniões destes através do matrimonio, como foi o caso de Dudu e Mariquinhas.

$\mathrm{Na}$ circunstancia de trocas de postais, os traços de comportamento e a simpatia das pessoas, alem da concordância das formas de pensar e agir entre elas, se manifestava mais importantes que as suas características físicas e a sua aparência. Semelhante procedimento de trocas de cartões postais fazia com que, no interior de um sistema patriarcal e patrimonial, as interações entre homens e mulheres viessem a fortalecer não a autonomia pessoal de ambos em relação as suas famílias de origem, mas, ao contrario, a sua sujeição às suas normas e costumes.

Assim é que a circulação de cartões postais entre pessoas de sexo diferentes deveria ser suficientemente discreta para que a moça pretendida não se sentisse insegura a ponto de nutrir ciúme de seu enamorado. No caso de uma rede social, este ciúme da correspondência da pessoa amada com outros poderia ocasionar situações embaraçosa entre ela e, por exemplo, suas amigas que também faziam parte de um mesmo sistema de troca. Os postais trocados entre Joaquininha Vieira e Mariquinhas e entre ela e Dudu são aqui um exemplo de que, no âmbito da trocas de cartões, saber separar as relações de amizade com aquelas que conduziriam, posteriormente, ao namoro, seria uma arte.

Os cartões escritos por Joaquininha para sua amiga tem por tema a amizade $A$ amizade é um sentimento real e nobre, sua fonte é pura e brota no coração), a pureza da alma diante dos dramas do coração e da fragilidade dos sentimentos ( $O$ coração é frágil como o vidro). Os postais escolhidos são novamente fotos de estúdios com figuras 
femininas em poses de ninfas ou com figuras de crianças e de seus brinquedos, sempre colocados em cenários que retratam são jardins ou bosques, repletos de flores. Já os cartões enviados ao amigo fala essencialmente do amor ( $O$ primeiro amor que entra no coração é o ultimo que sai da memória) e do sofrimento e do perdão como partes essenciais do sentimento amoroso ( $O$ amor é sempre belo, mas só é grande quando sofre, perdoa ou tem saudades.) Nestes postais temos as figuras femininas do teatro parisiense. No primeiro ela encontra-se numa pose totalmente frontal para o fotografo. Com um gesto aparentemente displicente, a modelo, com a mão esquerda, abre levemente uma cortina, onde se pode vislumbrar parte da vidraça de uma janela e com a esquerda segura o colar de contas. A cabeça da jovem esta levemente inclinada para a direita e seu olhar se dirige para o chão dando-lhe um ar de recato e timidez. Por outro lado, o outro postal traz a modelo numa pose de semi-perfil, num cenário formado novamente de cortinas, onde se destaca a presença de uma cadeira. A figura feminina usa um vestido de festa, de alça, decotado e com flores aplicadas. No pescoço um colar de perolas. A mão direita depositada ao acaso no espaldar de uma cadeira e a mão esquerda colocada sobre o quadril, com a palma da virada para cima. O uso de jóias, bracelete e anel neste braço talvez justifique a pose. Sofisticação, altivez e elegância é a marca da postura da figura feminina que não aparece de corpo inteiro. Duas pessoas de sexos diferentes, ambos fazendo parte de uma mesma rede social. Duas modalidades de escritas e duas formas de expressão de sentimentos para as quais a remetente necessita da perícia das palavras para traduzir seus pensamentos interiores distintos não traindo a confiança de ambos para com seus sentimentos a eles dedicados.

Neste sentido, tanto a moça como o rapaz deveriam saber conduzir as trocas entre eles e os outros de forma a que a pessoa de seu interesse não se se ofende e viesse a romper a relação de amizade, acabando com a esperança de um futuro namoro. Ainda que ao rapaz se permitisse, na escrita dos postais, maior liberdade em suas expressões afetivas que as moças, a verdade é que sob seus ombros pesava os riscos de ser considerado alguém de "má fé" ou "mal-intencionado".

A passagem da relação de amizade para a de namoro implicará no limite à conduta da moça por parte de sua família e do namorado no sentido de vigiar e controlar o seu comportamento com outros rapazes, mesmo os seus primos, tanto quanto nos espaços públicos, atuando no sentido de não lhe permitir exageros seja nos gestos, seja nas roupas, ou seja, ainda no "toilette".

$\mathrm{O}$ costume da troca de postais se torna, assim, um expediente para que moças e rapazes de um mesmo segmento social possam se conhecer e se ajustar até o momento decisivo em que a relação de amizade se transforma em uma relação "séria", seguindose então as normas tradicionais de namoro e noivado na época, e que mesmo assim não deveria se prolongar para que as trocas de caricias e confidencias conduzisse os noivos a intimidades inconvenientes. Neste contexto, as figuras do "caça-dotes" tanto quanto da "casadeira" seriam neutralizadas uma vez que a troca social presente nos cartões permitia aos rapazes e as moças avaliar ao longo do tempo o caráter e o temperamento de seus possíveis pretendentes.

Vamos apresentar agora uma sequência de postais enviados por Mariquinhas a Dudu, ou seja, de uma jovem para um rapaz. Na época, pelo teor hierárquico das interações que se teciam entre homens e mulheres, isto representa diferenças significativas para o caso de cartões enviados de um rapaz para uma moça. Observemos que nesta série, ao final, Mariquinhas se desculpa com Dudu por sua atitude no dia anterior. 
O primeiro cartão endereçado dia 04 de maio de 1904, passados mais de um ano de trocas de postais, e provavelmente com os jovens na condição social de namorados para sua rede de amigos e suas próprias famílias, traz um menino e uma menina no terraço de um palacete (lembra os palácios gregos pela presença das colunas e de uma floresta ao fundo) preparando-se para uma festa ou dança. Novamente aqui o personagem do rapaz é representado por uma jovem com trajes masculinos. O menino, vestindo uma bata em estilo grego rendada está ajoelhado em uma das pernas, ao lado e próximo de uma jovem menina, sentada num banco, e decora gentilmente o decote de seu vestido com um bouquet de flores. A menina, vestida também com uma bata, trás o cabelo e os ombros adornados de flores. A menina sorrindo acompanha com o olhar o gesto do jovem menino. A ausência de malicia e o caráter galante o gesto são destaque. Nos dizeres escritos por ela apenas afetuosas saudações da Mariquinhas.

O segundo cartão da série, postado dia 05 de maio de 1904 traz a representação dos mesmos personagens comentados acima, entretanto, neste postal temos o menino, nos mesmos trajes, olhando para o chão, com uma das mãos no ombro da jovem e outra segurando uma guirlanda de rosas que arrasta no chão, adornando o vestido da jovem. A menina em posição angelical, mãos reunidas no peito, quase em posição de prece, cabeça inclinada para a direita, olha por cima dos ombros para alguém fora da cena. Nestes postais Marquinhas ao mesmo tempo em que expressa seu arrependimento por seu comportamento ou atitude do dia anterior para com Dudu, lhe confessa seu sentimento de saudades (Peço-te que me desculpes de que eu fiz ontem. Saudades da Mariquinhas)

Podemos seguir a resposta que Dudu dá aos cartões que lhe foram encaminhados por Mariquinhas, em uma outra série de cartões postais que ele lhe envia, um dia após o ocorrido (06 de maio de 1904). Provavelmente teremos em Marquinhas uma jovem de "gênio forte", zelosa com relação a entrega de seus sentimentos mais íntimos e que lhe impunha certas exigências de conduta e comportamento, oscilando entre o recatado e o acanhamento em relação ao amado e, talvez, a paixão descontrolada e a manifestação prematura de cobrança de compromisso.

A encantadora série que Dudu lhe envia como gesto de perdão traz duas crianças, um menino, com trajes de padeiro, ofertando um embrulho de presente a uma menina, sentada numa mesa. Os rostos de ambos estão próximos, a menina olha o menino nos olhos e ele, com cabeça inclinada, têm os olhos baixos. Menina recebe o presente das mãos dos meninos, que apenas se tocam. Gestos e posturas insinuam um jogo de conquista entre ambos. Ao lado uma mesa, com uma cadeira vaga ao lado, com um livro nela depositado. No postal seguinte as duas crianças encontram-se sentadas frente a frente, $\mathrm{Na}$ mesa, entre eles, ao centro, um prato de doces. As crianças estão olhando fascinadas para as guloseimas. No próximo cartão vemos as duas crianças se deliciando comendo doces. A menina tem a cabeça inclinada sobre a mesa, e com a mão esquerda apoiada na sua beirada olha fascinada para o doce que esta segurando na mão direita. O menino sorrindo, olha diretamente para o fotografo. Ele tem um pedaço do doce na mão esquerda e na mão direita apoiada na perna direita. Na continuidade aparecem as duas crianças lambendo o recheio dos doces, ambos com a língua de fora. $\mathrm{O}$ menino segurando o doce com a mão esquerda apoiada sob a mesa e menina lambendo o doce que esta levando a boca, olhando para o lado esquerdo, sob seu ombro. A ideia é que isto seria uma "travessura", pois estariam decompondo o doce para chegar no recheio. Logo após, no penúltimo cartão as crianças aparecem comendo os últimos doces do prato colocado sobre a mesa. O menino e a menina abriram os 
doces, seguram cada parte com uma das mãos, um das partes do doce já esta na boca, sendo mordida. Menina mantém o olhar a esquerda, por cima de seus ombros. O menino está completamente absorto no doce que tem na boca. $\mathrm{O}$ ultimo da série apresenta as crianças após terem comido doces estão limpando as mãos e a boca com guardanapos de papel. Menino olha por cima da menina, abrindo um guardanapo que tapa parte de seu rosto e a ela olha para ele, passando o guardanapo no canto da boca para retirar as sobras dos doces comidos.

Dudu inicia sua correspondência com Mariquinhas já deixando-a a par do laço especial que os une a ponto de adquirir uma coleção de cartões para expressar seus sentimentos íntimos em relação a ela (Recebi mais dois números da mimosa serie que me reservaste. Dedico-te esta de 6 cartões). Ele sabe que esta série deve narrar uma aceitação formal de desculpas, as pazes com a jovem amada, alem de sugerir que o seu amor por ela lhe permite reconhecer nela virtudes que superam seus erros (Não tens de que pedir desculpa. Agradeço sinceramente a tua bondade. Saudades do Dudu). Assistimos nesta troca de cartões o sentimento amoroso moldando o ser amado. (Encarreguei o menininho de te oferecer um doce. Afetuosamente saúda-te Dudu) Amando Mariquinhas o jovem enamorado atribui uma forma acabada a sua relação com a jovem amada. Através do sentimento amoroso que ele nutre por sua amada ele se torna capaz de apreender suas ações, sejam elas quais forem, e integrá-los a si ( $E$ necessário "contrariar a raiz" diria a Bilac... eu o creio. Saudades do Dudu. O motivo do arrependimento de Mariquinhas e da aceitação das desculpas por Dud, jamais saberemos as suas razões e motivos. Mas o que esta série nos permite pensar no amor como um sentimento que modifica o seu objeto lhe atribuindo uma dimensão de transcendência. Os atos errôneos cometidos por Mariquinhas, sejam quais forem, por ser ela o objeto amoroso de Dudu, podem ser relevados pela simples expressão do seu arrependimento $(O$ arrependimento já é bem duro castigo por isto peço ainda mais uma vez a Santa que me perdoe e ela tão boa me perdoará sem duvida a minha injustiça e ingratidão, não é? Lembrar-se-á que sou um devoto fervorosíssimo. Saudades do Dudu) Dos cartões aqui apresentados, o ultimo desta série deixa evidente que as estórias narradas e encenadas nos cartões postais, através de fotografias realizadas em estúdios, assim como as imagens que as compõe (cenários e lugares; figurinos e adereços; gestos, fisionomias, posturas e expressões dos personagens) dialogam com as mensagens neles escritas, sendo raro a sua escolha se dar ao acaso. (Acabaram-se os doces e a serie também. Já achei o livro de poesias de Bilac. Esta a teu dispor. Saudades do Dudu)

Enviar cartões seriam assim formas usuais de troca de correspondência entre rapazes e moças e destes entre si que acompanhavam outros costumes da época tais como o de oferecer flores, livros e doces entre amigos como parte de gentilezas entre eles. Sem dúvida que vale lembrar a trocas de presentes, flores, doces e postais obedeciam ao caráter assimétrico das relações entre os sexos, com as moças comportado-se com o conveniente recato, pudor e cautela ao aceitar com gratidão o presente, e os rapazes tendo a liberdade de enviá-los com certa freqüência sem ser, entretanto, impositivo.

$\mathrm{O}$ recurso ao uso de versos e pensamentos de poetas assim como as imagens e temas sugestivos dos postais, tática utilizada por Dudu (versos de Olavo Bilac) em seu ultimo cartão recém comentado, seria uma forma de proteger o anonimato do remetente contra possíveis curiosidades da família e da rede de amigos a respeito de seus sentimentos íntimos além de preservar a pureza da mulher amada para que não se aluda 
a ela a situação das moças "perdidas" ou as "desavisadas" os conventos de religiosas e os reformatórios.

Para as jovens o meio de expressão do "falar amoroso" cercava-se das mesmas precauções e cautelas com um agravante maior que era de não macular a figura de pureza do ser amado. Uma série de dois cartões enviados por Mariquinhas a Dudu, em setembro de 1904, nos mostram a tragédia da mulher objeto amoroso comedido e recatado e na figura do ser amoroso em descoberta do seu desejo e da sua sexualidade. O cenário da série de cartões postais é um sofisticado jardim, com alamedas de arvores e esculturas. A cena traz dois jovens enamorados num banco de jardim, lendo um livro. Ambos os personagens, rapaz e a moça, são interpretados por duas jovens. $\mathrm{O}$ personagem do rapaz, um pouco de perfil, vestido com roupas e penteado de fins do séc. XVII, sentado no braço do banco apóia-se com uma das mãos no ombro da jovem e com a outra mão a auxilia a segurar o livro. A jovem, cabeça, inclinada, sentada no banco, de frente, com roupas e penteado de outra época (talvez final do séc. XIX) segura com suas duas mãos o livro. Ambos olham para as paginas do livro e encontramse totalmente envolvidos na sua leitura. Sobressai a atmosfera de isolamento e concentração dos enamorados. No cartão esta a frase em francês: Brandâme, como é divertido!!!, uma referencia ao cronista da corte de Luis XV. No postal o seguinte escrito, que inicialmente pensamos ser de sua autoria: Não suponhas que foge de teus olhos a luz, a meiga luz que te guiava. Cada vez mais a ti me sinto presa e consacro-te o amor que consagrava (cont.)

No outro cartão que o segue temos os dois jovens enamorados, em pé, juntos, abraçados, num jardim. A frente do casal esta um banco vazio. O rapaz quase de perfil, segurando uma bengala em sua mão direita, tem seu braço esquerdo entorno da cintura da moça, puxando-a contra si e olhando-a fixamente. A moça desviando o rosto um pouco, inclina-o e dirige seu olhar ao fotógrafo. Ela carrega na mão esquerda um livro. A pose da ideia de que estariam em pé, ao lado de uma estatua, em meio a um jardim. No cartão esta a frase em francês: Coloque o romance em ação, em referencia aos amores de Luis XV. Continuando seus pensamentos suspensos no cartão anterior, Mariquinhas, torna claro que se trata do pensamento de um poeta, valendo, entretanto, dele para, diante do sentimento de amor e desejo, dar voz aos seus pensamentos: Não penses que te fujo. Não te envolvas nas trevas da tristeza. Eu sou constante. Es a única estrela que me aclara e não posso esquecer-te um só instante (João Bastos). Com este finda-se a série que com muito prazer te enviei. Saudades Mariquinhas

Certamente que não se pode esquecer que as regras de conduta impostas pelos pais, noivos e maridos as suas filhas, noivas e esposas contrapõe-se com as liberdades que estes se arrogam para com as "mulheres da vida", e até para com algumas outras mulheres contando que não sejam as de suas famílias, para estas ultimas tratava-se de entregar-se aos apetites da natureza enquanto que para as primeiras reservava-se o lugar de esposa e mãe virtuosa, abnegada e honesta.

Nessas circunstancias, reza o manual do bom comportamento seria impraticável a possibilidade de experiências sexuais entre os namorados antes do casamento, pois para o caso da moça o "passo falso", a "queda" provocaria sua expulsão do lar paterno ou seu total ostracismo, principalmente se deste deslize resultasse o nascimento de uma criança ("fruto do pecado"). Para estas moças a moralidade da época reservava, fora do contexto dos conventos religiosos e os reformatórios, o destino da prostituição ou do amasiamento, isto se não fosse exigido do namorado a correção do erro, através de um casamento às pressas. 
Neste sentido, mais uma vez é importante lembrar que, nas cidades brasileiras, na época em que Dudu e Mariquinhas viviam seu caso de amor, as regras de namoro estabeleciam claramente que haveria hora e dia para o namoro e que os encontros e passeios não poderiam se estender até muito tarde da noite, momento em que predominava nas ruas os boêmios, as mulheres da vida, os vagabundos sem eira, nem beira. Em alguns lugares era comum o toque do sino da igreja determinar o tempo das juras e confidencias amorosas nas boas casas de família. Imagine-se o que provocou nas regras de namoro o advento da luz elétrica nos espaços públicos como subversão da noite como espaço de tempo de exercício do controle moral dos corpos e das mentes dos enamorados.

\section{Referências}

ARIÈS, Phillipe. A história social da familia e da criança. Rio de Janeiro, Zahar Editores, 1981.

ARIÈS, Phillipe. A familia e a cidade. In: Familia, Piscologia e Sociedade. G. Velho \& S Figuerira (Coords.) Rio de Janeiro, Zahar Editores, 1981.

AZEVEDO, Thales. As regras do namoro à antiga. São Paulo: Ática, 1986.

AZEVEDO, Thales. Namoro à antiga. In: Familia, Piscologia e Sociedade. G. Velho \& FIGUEIRA, Sérvulo e VELHO, Gilberto (Coords.) Rio de Janeiro, Zahar Editores, 1981.

AZEVEDO, Thales e MOTTA, Antônio. O Cotidiano e eeus Ritos: praia, namoro e Ciclos da Vida. Recife, Fundação Joaquim Nabuco, Editora Massangana, 2004.

FREIRE, Gilberto. Casa Grande e Senzala. Editora Record, Rio de Janeiro, 1998, cap. IV, $34^{\mathrm{a}}$ edição,.

FREIRE, Gilberto. Sobrados e Mocambos: decadência do patriarcado rural e desenvolvimento do urbano. São Paulo: Companhia Editora Nacional, 1936.

QUEIROZ, Maria Isaura Pereira de . São Paulo, Editora LTC, 1978.

SIMMEL, G. Cultura femenina y otros ensayos. Madrid, 1934. 